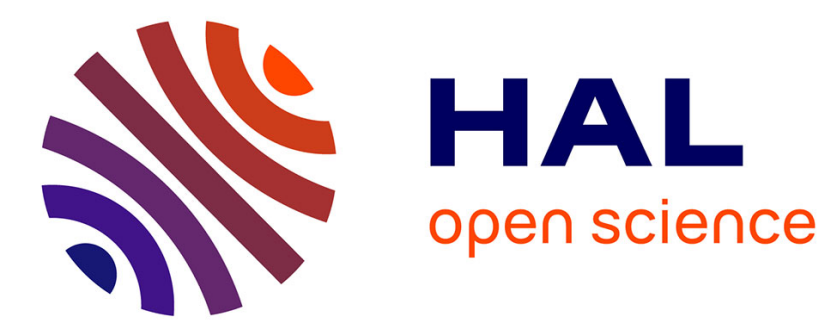

\title{
Mass-Radius relationships of small, highly irradiated exoplanets with small water mass fractions
}

\author{
Hugo Vivien, Artem Aguichine, Olivier Mousis, M. Deleuil, Emmanuel Marcq
}

\section{To cite this version:}

Hugo Vivien, Artem Aguichine, Olivier Mousis, M. Deleuil, Emmanuel Marcq. Mass-Radius relationships of small, highly irradiated exoplanets with small water mass fractions. European Planetary Science Congress. EPSC 2021, Sep 2021, Virtual Meeting, France. 10.5194/epsc2021-249 . insu03317763

\section{HAL Id: insu-03317763 \\ https://hal-insu.archives-ouvertes.fr/insu-03317763}

Submitted on 7 Aug 2021

HAL is a multi-disciplinary open access archive for the deposit and dissemination of scientific research documents, whether they are published or not. The documents may come from teaching and research institutions in France or abroad, or from public or private research centers.
L'archive ouverte pluridisciplinaire HAL, est destinée au dépôt et à la diffusion de documents scientifiques de niveau recherche, publiés ou non, émanant des établissements d'enseignement et de recherche français ou étrangers, des laboratoires publics ou privés. 
EPSC Abstracts

Vol. 15, EPSC2021-249, 2021, updated on 01 Aug 2021

https://doi.org/10.5194/epsc2021-249

European Planetary Science Congress 2021

(c) Author(s) 2021. This work is distributed under

the Creative Commons Attribution 4.0 License.

\section{Mass-Radius relationships of small, highly irradiated exoplanets with small water mass fractions}

\footnotetext{
Hugo Vivien ${ }^{1}$, Artem Aguichine ${ }^{1}$, Olivier Mousis ${ }^{1}$, Magali Deleuil $^{1}$, and Emmanuel Marcq ${ }^{2}$ ${ }^{1}$ Aix Marseille Univ, CNRS, CNES, LAM, Marseille, France

${ }^{2}$ LATMOS/IPSL, UVSQ Université Paris-Saclay, Sorbonne Université, CNRS, Guyancourt, France

This work aims to determine the mass-radius rela-tionships of highly irradiated $(500<$ Tirr $<2000 \mathrm{~K})$ small planets $(0.2<\mathrm{M}<2.3 \mathrm{M} \square)$ with water con-tents up to $5 \%$. To do so, we coupled an internalmodel of small terrestrial planets (Brugger et al.,2017) to the atmosphere model elaborated by Marcqet al. (2017, 2019), following the approach depictedin Aguichine et al. (2021) and Mousis et al. (2020).

We show that these planets, even with smallwater contents, can become strongly inflated andproduce large radii for small masses. We alsoshow that strongly irradiated small planets cannotsustain their atmospheres due to the lack of hy-drostatic stability, implying they cannot preserveany hydrosphere. The temperature and the watermass fraction are the key parameters controllingthe extent of inflation and the thickness of thesupercritical layer. An important amount of wateralso leads to the contraction of the rocky interior.However, the composition of the rocky interioronly has a limited impact on the final mass-radiusrelationship, and barely impacts the behavior of thehydrosphere.
} 